\title{
KUALITAS INSTRUMEN PENGENDALIAN PEMANFAATAN RUANG BERDASARKAN KELENGKAPAN MATERI KETENTUAN UMUM PERATURAN ZONASI RENCANA TATA RUANG WILAYAH DI KABUPATEN KENDAL
}

\author{
Jamilla Kautsary ${ }^{1}$ \\ Salmaa Shafira ${ }^{2}$ \\ Program Studi Perencanaan Wilayah dan Kota Universitas Islam Sultan Agung Semarang ${ }^{1,2}$ \\ Penulis Korespondensi e-mail: jamilla@unissula.ac.id
}

\begin{abstract}
General Provisions for Zoning Regulations are a tool for controlling space utilization. This tool contains general requirements for spatial use and for managng in all regency. This tool contains at least the rules of activity and the intensity of utilization of space, minimum standards of facilities and utilities, provisions on the use of space that were through by network system and special provisions. These minimum prerequisites sometimes cannot fulfill, consequently this making it difficult to implement control of spatial use. The purpose of this study is to evaluate the quality of the land use control instruments of Kendal regency. This research uses quantitative rationalistic deductive method, with descriptive empirical technical analysis. The results of this study indicate that the completeness of zoning regulations for spatial plan in the Kendal Regency didnt not in accordance with the minimum standards (the provisions of the activities, the provisions of building intensity and the minimum standard provisions for utilities and facilities were incomplete and these dint not according to standard). Some of the influencing factors include lack of understanding in compiling regional regulations and plurality of interests in spatial planning.
\end{abstract}

Keywords: Control, Utilization, Land, Zoning

\begin{abstract}
ABSTRAK
Ketentuan Umum Peraturan Zonasi merupakan satu alat pengendalian pemanfaatan Ruang. Alat ini berisi persyaratan pemanfaatan ruang secara umum dan ketentuan pengendaliannya di seluruh wilayah kabupaten. Alat ini minimal berisi aturan kegiatan dan intensitas pemanfaatan ruang, standart minimum sarana-prasarana, ketentuan pemanfaatan ruang yang dilewati sistem jaringan dan ketentuan khusus. Prasyarat minimal ini kadang tidak bisa dipenuhi, akibatnya menyulitkan dalam implementasi pengendalian pemanfaatan ruang. Tujuan penelitian ini untuk mengevaluasi kualitas instrumen pengendalian (Ketentuan Umum Peraturan Zonasi) kabupaten Kendal. Penelitian ini menggunakan metode deduktif kuantitatif rasionalistik, dengan teknis analisis desktriptif empiris. Hasil penelitian ini menunjukkan bahwa kelengkapan peraturan zonasi dalam rencana tata ruang wilayah Kabupaten Kendal belum sesuai dengan standart minimum (ketentuan kegiatan, ketentuan intensitas bangunan dan ketentuan standart minimal prasarana dan sarana tidak lengkap dan tidak sesuai standart). Beberapa faktor yang mempengaruhi diantaranya adalah kekurang pahaman penyususun peraturan daerah dan kemajemukan kepentingan dalam penyusunan tata ruang.

Kata kunci: Pengendalian, Pemanfaatan, Lahan, Zonasi
\end{abstract}


Jurnal Planologi Vol. 16, No. 1, April 2019

Available : http://jurnal.unissula.ac.id/index.php/psa

\section{PENDAHULUAN}

Pengendalian pemanfaatan ruang sesuai dengan ketentuan umum poin 15 UndangUndang Penataan Ruang No. 26 Tahun 2007 merupakan upaya untuk mewujudkan tertib tata ruang. Upaya pengendalian ini dilakukan dengan cara penetapan peraturan zonasi, perizinan, pemberian insentif dan disinsentif, serta pengenaan sanksi (Pasal 35). Peraturan zonasi ini dalam undang-undang tersebut dibagi sesuai tingkatan wilayah yang dikendalikan. Peraturan zonasi di tingkat kabupaten sesuai dengan Pasal 26 berupa ketentuan umum aturan zonasi. KUPZ ini merupakan ketentuan umum yang mengatur pemanfaatan ruang dan ketentuan pengendalian pemanfaatan ruang untuk setiap klasifikasi peruntukan ruang dan ruang sekitar yang dilewati jaringan prasarana sesuai dengan RTRW Kabupaten (Peraturan Menteri Agraria dan Tata Ruang No. 1 Tahun 2018 tentang Pedoman Penyusunan RTRW Provinsi, Kabupaten, dan Kota).

Peraturan zoning digunakan pertama kali di New York. Peraturan ini awalnya hanya berisi aturan ketinggian bangunan dan jarak antara bangunan dengan jalan di sebelahnya (Enni Lindia Mayona, dkk, 2009). Saat ini, peraturan zonasi di Amerika merupakan piranti atau alat dalam perencanaan dan pengendalian pemanfaatan lahan yang sangat ketat (Merriam, 2005). Peraturan zonasi tersebut juga dapat membatasi jenis dan lokasi dari struktur. Peraturan ini terberlaku sama di setiap kabupaten, tetapi dapat bervariasi dari satu kabupaten ke kabupaten lainnya. Peraturan-peraturan ini sering mengontrol: lokasi bangunan, tinggi, lebar, kepejalan, jenis pondasi bangunan, jumlah dan ukuran bangunan dan struktur lainnya, persentase ruang yang ditempati (koefisien dasar bangunan), ukuran halaman depan dan ruang terbuka lainnya, kepadatan dan distribusi populasi, konservasi lahan dan air, konservasi lahan pantai, pencahayaan/akses sinar matahari serta kontrol banjir (Leageu of Minnesota Citie, 2017).

Sementara peraturan zonasi untuk kawasan lindung/konservasi berisi kriteria perlindungan sumber daya berbasis tujuan (fisik dan biologis) dan di kawasan pengembangan berisi arahan pengembangan yang tepat, yang akhirnya mengarah pada pembuatan rencana untuk setiap zona (Farzam Hastilat all, 2016). Zonasi tersebut merupakan bagian utama dari prinsip-prinsip perencanaan, yang sekarang dianggap sebagai alat paling penting untuk pengelolaan di kawasan lindung (Walther, 1986; Sabtini et al, 2007). Peraturan zonasi sebagai dasar pengendalian pemanfaatan ruang harus berlandaskan penetapan zonasi yang tepat. Penetapan zonasi adalah kegiatan pembagian lingkungan kota ke dalam zona-zona atau kawasan fungsional dan menetapkan aturan 
Jurnal Planologi Vol. 16, No. 1, April 2019

pengendalian pemanfaatan ruang atau ketentuan hukum yang berbeda-beda di tiap zona (Barnett, 1982).

Tujuan utama penetapan aturan zonasi adalah untuk menjamin pembangunan yang akan dilakukan dapat mencapai standart kualitas minimum lokal (kesehatan, keamanan, dan kesejahteraan), pembangunan baru tidak mengganggu pemanfaat atau pengguna ruang yang telah ada, pemeliharaan nilai properti, pemeliharaan lingkungan dan penetapan nilai kualitasnya, serta untuk penyediaan aturan yang seragam di setiap zonasi (Zulkaidi dan Natalivan, 2008)

Fungsi ketentuan umum aturan zonasi ini dalam pengendalian pemanfaatan sesuai dengan Peraturan Menteri Agraria dan Tata Ruang No. 1 Tahun 2018 adalah sebagai dasar pertimbangan untuk pengawasan penataan ruang, penyeragaman ketentuan di peruntukan zona yang sama; penyusunan peraturan zonasi rencana rinci dan pengendalian pemanfaatan ruang di setiap zona kabupaten dan sebagai dasar pemberian izin pemanfaatan ruang.

Peraturan zonasi sebagai dasar pengendalian pemanfaatan lahan melalui pengawasan dan perizinan harus memiliki dasar penetapan yang jelas. Kondisi ini menuntut KUPZ memiliki kejelasan dasar dalam pengaturan/ketentuan hukum di tiap zona. Prasyarat pengendalian pemanfaatan ruang bisa dengan baik (efektif dan efisien) menurut Zulkaidi dan Natalivan (2008) adalah produk rencana harus baik dan berkualitas dan didukungan adanya informasi yang akurat terhadap praktek-praktek pengendalian pemanfaatan ruang.

Standart kualitas yang baik untuk menyusun KUPZ yang berlaku Indonesia secara umum adalah mengikuti tandart minimal bidang pentaan ruang khususnya Pedoman Teknis Penyusunan KUPZ di Tingkat Kabupaten (Peraturan Menteri Agraria dan Tata Ruang No. 1 Tahun 2018 tentang Pedoman Penyusunan RTRW Provinsi, Kabupaten dan Kota atau yang sebelumnya Peraturan Menteri Pekerjaan Umum No. 16 Tahun 2009). Jika standart ini tidak terpenuhi, akibatnya produk aturan tidak bisa diimplementasikan dengan baik dan sebagai akibatnya pengendalian pemanfaatan ruang juga tidak bisa dilaksanakan.

Indikasi dari kegagalan implementasi produk pengendalian ini adalah adanya pelanggaran pemanfaatan ruang yang ditunjukkan dengan adanya simpangan pemanfaatan ruang. Di Kabupaten Kendal luasan simpangan penggunaan lahan ini cukup besar. Di Daerah Aliran Sungai (DAS) Blorong Kabupaten Kendal di kawasan lindungnya, sebagian berubah menjadi kawasan budidaya seluas 555,87 Ha, di DAS Bodri seluas 638,99 Ha dan di DAS Lampir seluas 70, 40 Ha (Hasil Kajian Pemerintah Provinsi Jawa Tengah melalui 
Studi Pengendalian Pemanfaatan Ruang tahun 2017). Data simpangan untuk RTRW Kendal secara umum juga menunjukkan simpangan lahan cukup besar. Simpangan lahan permukiman 1646, $39 \mathrm{Ha}$, simpangan lahan untuk industri 255,56 Ha, simpangan lahan perkebunan 286,1 Ha dan lahan sawah 97,15 Ha atau total seluas 2284,2 Ha (Laporan Peninjauan Kembali RTRW Kabupaten Kendal, 2016).

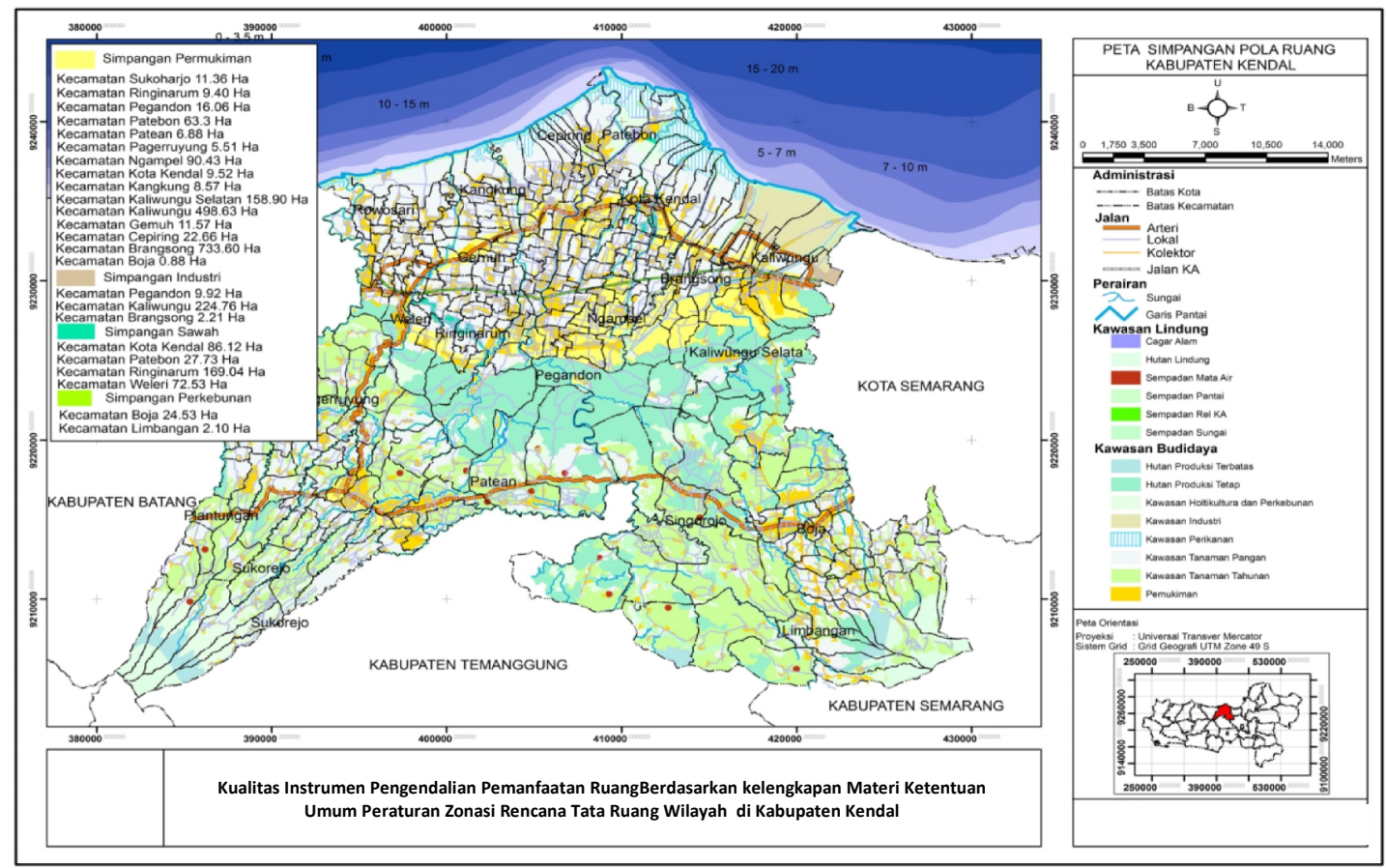

Gambar 1. Peta Simpangan Pemanfaatan Lahan Terhadap Rencana Pola Ruang Kab. Kendal. Sumber: Laporan Peninjauan Kembali RTRW Kabupaten Kendal, 2016

\section{METODOLOGI}

Tujuan penelitian ini dari latar permasalahan diatas adalah untuk menemukan kualitas kelengkapan instrumen pengendalian pemanfaatan ruang (KUPZ) dalam RTRW Kabupaten Kendal. Penelitian ini menggunakan metode pendekatan dedukatif kualitatif rasionalistik kengan teknis analisis komparasi antara kondisi empiris KUPZ dalam Peraturan Daerah RTRW Kabupaten Kendal dengan Pedoman Penyusunan KUPZ dalam Peraturan Menteri Agraria dan Tata Ruang No. 1 Tahun 2018. Tahapan yang dilakukan peneliti, dalam kajian ini pertama adalah mengidentifikasikan standart minimum ketentuan KUPZ dalam peraturan. Kedua memilih pasal-pasal yang memuat aturan zonasi dalam Peraturan Daerah Kabupaten Kendal. Ketiga menganalisis kelengkapan aturan kegiatan, aturan intensitas bangunan dan kelengkapan standart pelayanan minimum. 
Jurnal Planologi Vol. 16, No. 1, April 2019

Keempat memberikan kesimpulan dan saran. Hasil penelitian diharapkan dapat menjadi masukan bagi Pemerintah Daerah Kabupaten Kendal yang saat ini sedang melakukan revisi RTRW agar KUPZ RTRW menjadi lebih berkualitas dan dapat dijadikan acuan untuk pengendalian pemanfaatan ruang di Kabupaten Kendal.

\section{HASIL DAN PEMBAHASAN}

Kondisi ruang wilayah di Indonesia, saat ini sangat jauh dengan harapan tujuan penataan ruang untuk menciptakan ruang yang aman, nyaman, produktif dan berkenjutan. Penyelenggaraan penataan ruang sesuai dengan PP No. 15 Tahun 2010 meliputi, perencanaan, pemanfaatan, dan pengendalian. Ketiga komponen ini sangat mempengaruhi antar satu komponen dengan komponen lainnya. Jika dalam pelaksanaannya salah satu komponen jelek, maka hasil yang didapatkan adalah jelek. Dampaknya adalah meningkatnya intensitas bencana dan kerusakan alam.

Pada tahap pelaksanaan rencana tata ruang, peran pengendalian mulai dari penetapan aturan zonasi sampai pengenaan sanksi sangatlah penting. Jika pada waktu perencanaan penetapan aturan zonasinya dilakukan secara asal-asalan, maka pada tahap berikutnya sebagus apapun dilaksanakan maka hasilnya akan tetap buruk. Baik buruknya kualitas KUPZ ini di Indonesia dapat dilihat dari seberapa besar aturan standart dan kriteria minimal penyusunan KUPZ di laksanakan. Standart penyusunan KUPZ ini didasarkan pada pedoman minimal bidang perencanaan yang dikeluarkan oleh kementrian terkait sesuai dengan tingkatannya.

Kualitas KUPZ sebagai instrumen pengendalian pemanfaatan ruang dalam penelitian sesuai dengan ketentuan yang berlaku akan dilihat berdasarkan kelengkapan materi KUPZ RTRW sesuai dengan peraturan yang berlaku di Indonesia. Standart teknis yang dimaksudkan adalah ketentuan kelengkapan dan kedalaman materi KUPZ sesuai dengan Peraturan Menteri Agraria dan Tata Ruang No. 1 Tahun 2018 tentang Pedoman Penyusunan RTRW Provinsi, Kabupaten, dan Kota.

Standart minimal kedalaman dan kelengkapan materi KUPZ dalam peraturan tersebut minimal terdisi dari:

1) Kegiatan pemanfaatan ruang yang terdiri dari:

a) kegiatan yang diperbolehkan,

b) kegiatan yang diperbolehkan dengan syarat, dan

c) kegiatan yang tidak diperbolehkan 
2) Pada setiap kawasan peruntukan di ruang darat, laut, udara, dan dalam bumi;

3) Intensitas pemanfaatan ruang pada setiap zona/peruntukan minimal meliputi:
a) koefisien dasar hijau;
b) koefisien dasar bangunan;
c) koefisien lantai bangunan;
d) garis sempadan bangunan.

4) Sarana dan prasarana minimum sebagai dasar fisik lingkungan untuk mendukung pengembangan kawasan;

5) Ketentuan lain yang dibutuhkan misalnya, pemanfaatan ruang pada zona-zona yang dilewati oleh sistem jaringan sarana dan prasarana wilayah kabupaten mengikuti ketentuan perundang-undangan yang berlaku;

Guna melihat kelengkapan KUPZ dalam RTRW Kabupaten Kendal, Peneliti menggunakan parameter 1), 2) 3) dan 4). Hasil yang didapat dengan mengkomparasikan kondisi fakta empiris KUPZ dengan standart minimal di atas secara lengkap dapat dilihat pada tabel 1, 2 dan 3.

A. Kelengkapan ketentuan kegiatan (pada tabel 1), menunjukkan bahwa:

1) Dari total 9 pasal yang mengatur kegiatan pemanfaatan ruang di sekitar sistem jaringan terlihat bahwa:
a. semua pasal mencantumkan aturan diperbolehkan (100\%);
b. semua pasal tidak mengatur ketentuan bersyarat $(0 \%)$, dan
c. 7 pasal yang mengatur ketentuan tidak diperbolehkan (70\%).

2) Dari total 10 poin pada 5 Pasal dan ayat yang mengatur kawasan lindung, menunjukkan:
a. keseluruhan pasal mencantumkan aturan dizinkan;
b. 1 pasal mencantumkan aturan bersyarat;
c. keseluruhan pasal mencantumkan kegiatan yang tidak diizinkan.

3) Dari total 10 aturan (dalam 10 Pasal), yang mengatur peruntukan kawasan budidaya menunjukkan:
a. 9 pasal sudah mencantumkan ketentuan kegiatan yang diperbolehkan;
b. 2 pasal mencantumkan ketentuan besyarat dan
c. 7 pasal mencantumkan ketentuan kegiatan tidak diizinkan 
Jurnal Planologi Vol. 16, No. 1, April 2019

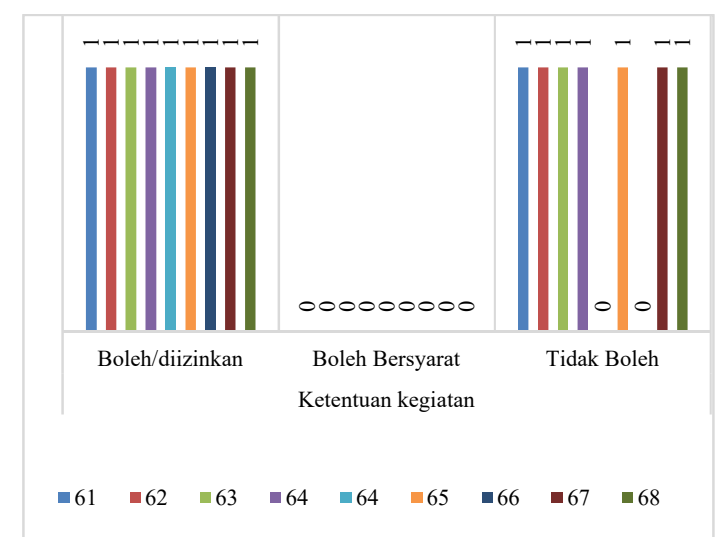

Aturan Kegiatan di Ruang yang Dilewati Sistem Jaringan



Aturan Kegiatan di Kawasan Lindung

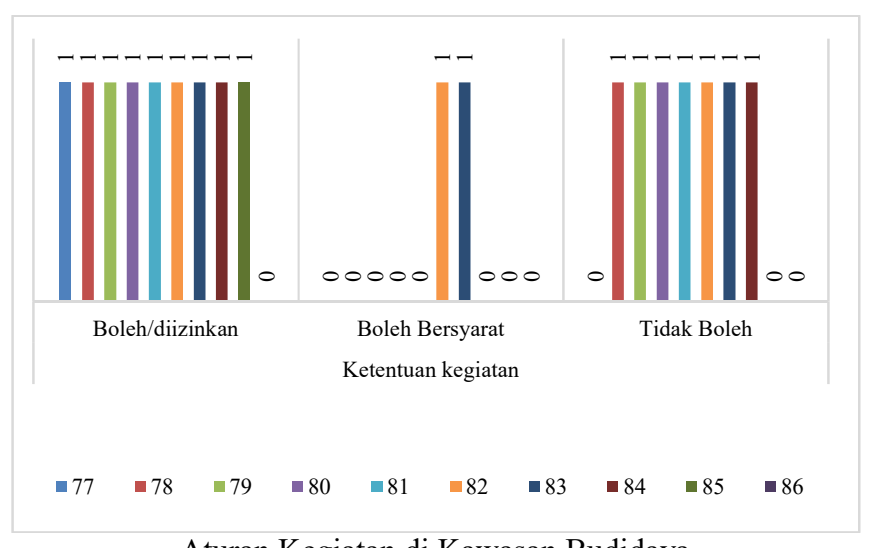

Aturan Kegiatan di Kawasan Budidaya

Gambar 2. Grafik Kelengkapan Aturan Kegiatan Sumber: Tabel 1, 2016

Tabel 1. Kelengkapan Aturan Kegiatan

\begin{tabular}{|c|c|c|c|c|c|c|}
\hline \multirow[b]{2}{*}{ No. } & \multirow[b]{2}{*}{ Pasal } & \multirow[b]{2}{*}{ Tentang } & \multicolumn{3}{|c|}{ Ketentuan kegiatan } & \multirow{2}{*}{$\begin{array}{l}\text { Keterangan } \\
\text { (Total) }\end{array}$} \\
\hline & & & $\begin{array}{l}\text { Boleh/di } \\
\text { izinkan }\end{array}$ & $\begin{array}{c}\text { Boleh } \\
\text { Bersyarat }\end{array}$ & $\begin{array}{l}\text { Tidak } \\
\text { Boleh }\end{array}$ & \\
\hline A & \multicolumn{6}{|c|}{ Ruang yang dilewati sistem jaringan } \\
\hline 1 & 61 & jaringan jalan & 1 & 0 & 1 & \multirow{10}{*}{$\begin{array}{l}\text { Dari total } 9 \text { pasal } \\
\text { semuanya mencantumkan } \\
\text { aturan diperbolehkan, } \\
\text { semuanya tidak mengatur } \\
\text { ketentuan bersyarat, dan } \\
\text { hanya } 7 \text { pasl yang } \\
\text { mengatur ketentuan tidak } \\
\text { diperbolehkan }\end{array}$} \\
\hline 2 & 62 & prasarana transportasi darat & 1 & 0 & 1 & \\
\hline 3 & 63 & prasarana perkeretaapian & 1 & 0 & 1 & \\
\hline 4 & 64 & prasarana transportasi laut & 1 & 0 & 1 & \\
\hline 5 & 64 & alur pelayaran & 1 & 0 & 0 & \\
\hline 6 & 65 & jaringan energi & 1 & 0 & 1 & \\
\hline 7 & 66 & $\begin{array}{l}\text { jaringan telekomunikasi dan } \\
\text { informatika }\end{array}$ & 1 & 0 & 0 & \\
\hline 8 & 67 & jaringan sumber daya air & 1 & 0 & 1 & \\
\hline \multirow[t]{2}{*}{9} & 68 & jaringan prasarana lingkungan & 1 & 0 & 1 & \\
\hline & & & 9 & 7 & 7 & \\
\hline $\mathrm{B}$ & \multicolumn{6}{|c|}{ Pola Ruang } \\
\hline B1 & \multicolumn{6}{|c|}{ Kawasan Lindung } \\
\hline 1 & 70 & Hutan Lindung & 1 & 0 & 1 & \multirow{4}{*}{$\begin{array}{l}\text { Dari total } 10 \text { poin pada } 5 \\
\text { Pasal dan ayat yang } \\
\text { mengatur kawasan } \\
\text { lindung, kseluruhan sudah } \\
\text { mencantumkan aturan }\end{array}$} \\
\hline 2 & 71 & $\begin{array}{l}\text { Kawasan yang memberikan } \\
\text { perlindungan di bawahnya }\end{array}$ & 1 & 0 & 1 & \\
\hline & 72 & Kawasan perlindungan setempat & & & & \\
\hline & & a. Sempadan Pantai & 1 & 1 & 1 & \\
\hline
\end{tabular}


Jurnal Planologi Vol. 16, No. 1, April 2019

\begin{tabular}{|c|c|c|c|c|c|c|}
\hline \multirow[b]{2}{*}{ No. } & \multirow[b]{2}{*}{ Pasal } & \multirow[b]{2}{*}{ Tentang } & \multicolumn{3}{|c|}{ Ketentuan kegiatan } & \multirow{2}{*}{$\begin{array}{l}\text { Keterangan } \\
\text { (Total) }\end{array}$} \\
\hline & & & $\begin{array}{c}\text { Boleh/di } \\
\text { izinkan }\end{array}$ & $\begin{array}{c}\text { Boleh } \\
\text { Bersyarat }\end{array}$ & $\begin{array}{l}\text { Tidak } \\
\text { Boleh } \\
\end{array}$ & \\
\hline & & $\begin{array}{lll}\text { b. Sempadan Sungai, } & \text { Kawasan } \\
\text { Sekitar Waduk, } & \text { Embung, } \\
\text { Telaga, Laguna } & \\
\end{array}$ & 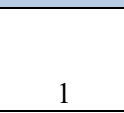 & 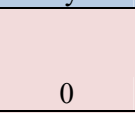 & 1 & \multirow{8}{*}{ 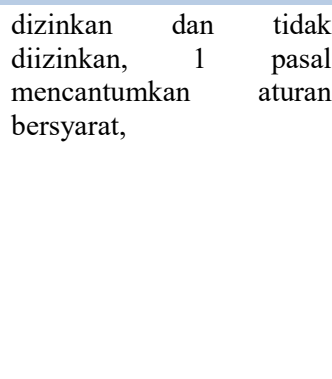 } \\
\hline & & c. Sempadan Mata Air & 1 & 0 & 1 & \\
\hline \multirow[t]{3}{*}{3} & 73 & Kawasan suaka alam & 1 & 0 & 1 & \\
\hline & & a. Kawasan pelestarian alam & 1 & 0 & 1 & \\
\hline & & b. Kawasan cagar budaya & 1 & 0 & 1 & \\
\hline 4 & 74 & Kawasan lindung geologi & 1 & 0 & 1 & \\
\hline \multirow[t]{2}{*}{5} & 75 & Kawasan rawan bencana & 1 & 0 & 1 & \\
\hline & & & 10 & 1 & 10 & \\
\hline B2 & \multicolumn{6}{|c|}{ Kawasan Budidaya } \\
\hline 1 & 77 & Hutan Produksi & 1 & 0 & 0 & \multirow{11}{*}{$\begin{array}{lr}\text { Dari total } 10 \text { aturan (dalam } \\
10 \text { Pasal, 9 pasal sudah } \\
\text { mencantumkan } & \text { ketentuan } \\
\text { kegiatan } & \text { yang } \\
\text { diperbolehkan, } 2 \text { pasal } \\
\text { mencantumkan ketentuan } \\
\text { besyarat dan } 7 \text { pasal } \\
\text { mencantumkan ketentuan } \\
\text { kegiatan tidak diizinkan }\end{array}$} \\
\hline 2 & 78 & Hutan Rakyat & 1 & 0 & 1 & \\
\hline 3 & 79 & Pertahian & 1 & 0 & 1 & \\
\hline 4 & 80 & Perkebunan & 1 & 0 & 1 & \\
\hline 5 & 81 & Perikanan & 1 & 0 & 1 & \\
\hline 6 & 82 & Pertambangan & 1 & 1 & 1 & \\
\hline 7 & 83 & Kawasan Peruntukan Industri & 1 & 1 & 1 & \\
\hline 8 & 84 & Pariwisata & 1 & 0 & 1 & \\
\hline 9 & 85 & Permukiman & 1 & 0 & 0 & \\
\hline \multirow[t]{2}{*}{10} & 86 & Pesisir dan laut & 0 & 0 & 0 & \\
\hline & & & 9 & 2 & 7 & \\
\hline
\end{tabular}

Sumber: Hasil Analisis, 2019

Keterangan Tabel: 1 ada, 0 tidak ada

Tabel 2. Kelengkapan Aturan Intensitas Bangunan

\begin{tabular}{|c|c|c|c|c|c|c|c|}
\hline No & Pasal & Tentang & KDB & $\begin{array}{c}\mathrm{KL} \\
\mathrm{B}\end{array}$ & $\mathrm{KDH}$ & $\begin{array}{l}\text { Sempa- } \\
\text { dan }\end{array}$ & Keterangan \\
\hline $\mathrm{A}$ & \multicolumn{6}{|c|}{ Ruang yang dilewati sistem jaringan } & \\
\hline 1 & 61 & jaringan jalan & 0 & 0 & 0 & 1 & \multirow{9}{*}{$\begin{array}{l}\text { Keterangan ketentuan } \\
\text { intensitas ruang yang } \\
\text { dilewati oleh sistem } \\
\text { jaringan menunjukan } \\
\text { hanya } 3 \text { dati } 9 \text { Pasal yang } \\
\text { mencantumkan KDH, dan } \\
3 \text { yang mencantumkan } \\
\text { ketentuan sempadan. }\end{array}$} \\
\hline 2 & 62 & prasarana transportasi darat & 0 & 0 & 0 & 0 & \\
\hline 3 & 63 & prasarana perkeretaapian & 0 & 0 & 0 & 1 & \\
\hline 4 & 64 & prasarana transportasi laut & 0 & 0 & 0 & 0 & \\
\hline 5 & 64 & alur pelayaran & 0 & 0 & 0 & 0 & \\
\hline 6 & 65 & jaringan energi & 0 & 0 & 1 & 0 & \\
\hline 7 & 66 & $\begin{array}{l}\text { jaringan telekomunikasi dan } \\
\text { informatika }\end{array}$ & 0 & 0 & 0 & 0 & \\
\hline 8 & 67 & jaringan sumber daya air & 0 & 0 & 1 & 1 & \\
\hline \multirow[t]{2}{*}{9} & 68 & jaringan prasarana lingkungan & 0 & 0 & 1 & 0 & \\
\hline & & & 0 & 0 & 3 & 3 & \\
\hline $\mathrm{B}$ & \multicolumn{6}{|c|}{ Pola Ruang } & \\
\hline B1 & \multicolumn{6}{|c|}{ Kawasan Lindung } & \\
\hline 1 & 70 & Hutan Lindung & 0 & 0 & 0 & 0 & \multirow{11}{*}{$\begin{array}{l}\text { Keterangan ketentuan } \\
\text { intensitas ruang yang } \\
\text { ditetapkan sebagai } \\
\text { kawasan lindung } \\
\text { menunjukan hanya } 3 \text { dari } \\
11 \text { Pasal yang } \\
\text { mencantumkan KDH dan } \\
\text { ini pada posisi/letak yang } \\
\text { tidak semestinya. dan } 3 \\
\text { yang mencantumkan } \\
\text { ketentuan sempadan } \\
\text { (sudah sesuai dengan } \\
\text { ketentuan) }\end{array}$} \\
\hline \multirow[t]{5}{*}{2} & 71 & $\begin{array}{l}\text { Kawasan yang memberikan } \\
\text { perlindungan di bawahnya }\end{array}$ & 0 & 0 & 0 & 0 & \\
\hline & 72 & Kawasan perlindungan setempat & & & & & \\
\hline & & a. Sempadan Pantai & 0 & 0 & 1 & 1 & \\
\hline & & $\begin{array}{l}\text { b. Sempadan Sungai, Kawasan } \\
\text { Sekitar Waduk, Embung, } \\
\text { Telaga, Laguna }\end{array}$ & 0 & 0 & 1 & 1 & \\
\hline & & c. Sempadan Mata Air & 0 & 0 & 1 & 1 & \\
\hline \multirow[t]{3}{*}{3} & 73 & Kawasan suaka alam & 0 & 0 & 0 & 0 & \\
\hline & & a. Kawasan pelestarian alam & 0 & 0 & 0 & 0 & \\
\hline & & b. Kawasan cagar budaya & 0 & 0 & 0 & 0 & \\
\hline 4 & 74 & Kawasan lindung geologi & 0 & 0 & 0 & 0 & \\
\hline 5 & 75 & Kawasan rawan bencana & 0 & 0 & 0 & 0 & \\
\hline
\end{tabular}


Jurnal Planologi Vol. 16, No. 1, April 2019

\begin{tabular}{|c|c|c|c|c|c|c|c|}
\hline No & Pasal & Tentang & KDB & $\begin{array}{c}\mathrm{KL} \\
\mathrm{B}\end{array}$ & $\mathrm{KDH}$ & $\begin{array}{c}\text { Sempa- } \\
\text { dan }\end{array}$ & Keterangan \\
\hline & & & 0 & 0 & 3 & 3 & \\
\hline B2 & \multicolumn{6}{|c|}{ Kawasan Budidaya } & \\
\hline 1 & 77 & Hutan Produksi & 0 & 0 & 0 & 0 & \multirow{10}{*}{$\begin{array}{l}\text { Keterangan ketentuan } \\
\text { intensitas ruang dikawasan } \\
\text { budidaya penekanan sudah } \\
\text { sesuai di permukiman dan } \\
\text { industri, hanya di } \\
\text { budidaya lain perlu juga } \\
\text { dipertimbangkan } \\
\text { khususnya di } \\
\text { pertambangan, pariwisata. }\end{array}$} \\
\hline 2 & 78 & Hutan Rakyat & 0 & 0 & 0 & 0 & \\
\hline 3 & 79 & Pertahian & 0 & 0 & 0 & 0 & \\
\hline 4 & 80 & Perkebunan & 0 & 0 & 0 & 0 & \\
\hline 5 & 81 & Perikanan & 0 & 0 & 0 & 0 & \\
\hline 6 & 82 & Pertambangan & 0 & 0 & 0 & 0 & \\
\hline 7 & 83 & Kawasan Peruntukan Industri & 1 & 0 & 1 & 0 & \\
\hline 8 & 84 & Pariwisata & 0 & 0 & 0 & 0 & \\
\hline 9 & 85 & Permukiman & 1 & 0 & 1 & 0 & \\
\hline \multirow[t]{2}{*}{10} & 86 & Pesisir dan laut & 0 & 0 & 0 & 0 & \\
\hline & & & 2 & 0 & 2 & 0 & \\
\hline
\end{tabular}

Sumber: Hasil Analisis, 2019

Keterangan Tabel: 1 ada, 0 tidak ada

B. Kelengkapan aturan intensitas pemanfaatan ruang pada setiap zona/peruntukan (pada tabel 2):

1) Keterangan ketentuan intensitas ruang yang dilewati oleh sistem jaringan menunjukan:

a. 3 dari 9 Pasal mencantumkan $\mathrm{KDH}$ (jaringan energi, jaringan sumber daya air, jaringan prasarana lingkungan);

b. 3 dari 9 Pasal mencantumkan ketentuan sempadan (jaringan jalan, prasarana perkeretaapian, jaringan sumber daya air).

2) Keterangan ketentuan intensitas ruang yang ditetapkan sebagai kawasan lindung menunjukan:

a. 3 dari 11 Pasal yang mencantumkan $\mathrm{KDH}$ dan ini pada posisi/letak yang tidak semestinya (sempadan pantai; sempadan sungai, kawasan sekitar waduk, embung, telaga, laguna;sempadan mata air)

b. 3 yang mencantumkan ketentuan sempadan (sudah sesuai dengan ketentuan)

3) Keterangan ketentuan intensitas ruang di kawasan budidaya:

a. penekanan sudah sesuai di permukiman terdapat ketentuan intensitas KDB dan $\mathrm{KDH}$;

b. kawasan peruntukan industri terdapat ketentuan intensitas KDB dan KDH. 
Jurnal Planologi Vol. 16, No. 1, April 2019 Available : http://jurnal.unissula.ac.id/index.php/psa

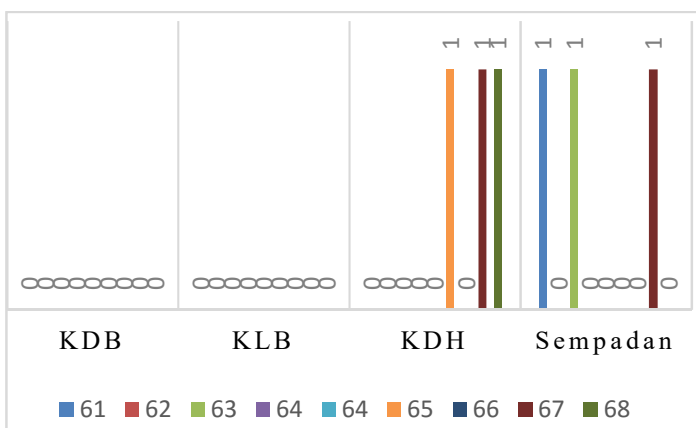

Aturan Intensitas di Ruang Dilewati Sisem Jaringan

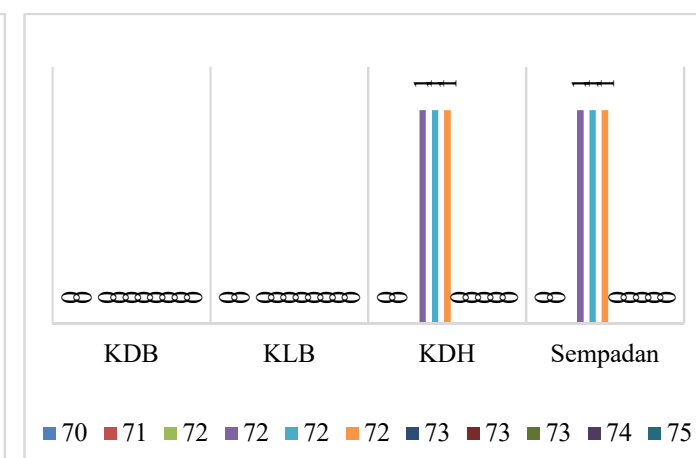

Aturan Intensitas Ruang di Kawasan Lindung

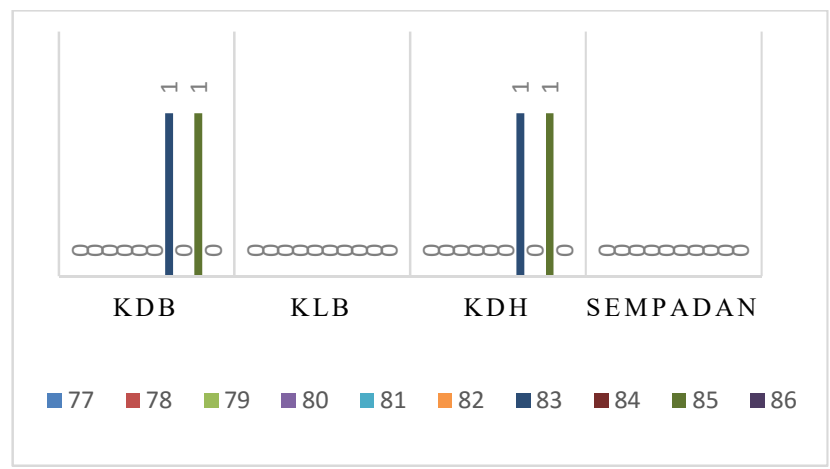

Aturan Intensitas Ruang di Kawasan Budidaya

Gambar 3. Grafik Kelengkapan Aturan Intensitas Bangunan Sumber: Tabel 2, 2016 
Jurnal Planologi Vol. 16, No. 1, April 2019

Available : http://jurnal.unissula.ac.id/index.php/psa

Tabel 3. Kelengkapan Standart Minimal Prasarana dan Sarana

\begin{tabular}{|c|c|c|c|c|c|}
\hline No & Pasal & Tentang & $\begin{array}{c}\text { Prasa- } \\
\text { rana }\end{array}$ & $\begin{array}{c}\text { Sara } \\
\text { na }\end{array}$ & Keterangan \\
\hline A & \multicolumn{5}{|c|}{ Ruang yang dilewati sistem jaringan } \\
\hline 1 & 61 & jaringan jalan & 1 & 1 & $\begin{array}{l}\text { Prasarana: sepanjang sisi jalan ; Sarana: bangunan fungsi } \\
\text { penunjang (rambu-rambu, marka, pengarah, dan pengaman } \\
\text { jalan, penerangan jalan) }\end{array}$ \\
\hline 2 & 62 & prasarana transportasi darat & 1 & 1 & $\begin{array}{l}\text { Prasarana: jaringan jalan primer ; Sarana: terminal, sarana } \\
\text { fasilitas umum }\end{array}$ \\
\hline 3 & 63 & prasarana perkeretaapian & 1 & 0 & Prasarana: jaringan jalur kereta api \\
\hline 4 & 64 & prasarana transportasi laut & 1 & 0 & Prasarana: jaringan transportasi laut \\
\hline 5 & 64 & alur pelayaran & 1 & 0 & Prasarana: badan air di sepanjang alur pelayaran \\
\hline 6 & 65 & jaringan energi & 1 & 1 & $\begin{array}{l}\text { Prasarana: jaringan SUTT, jaringan SUTET, jalur transmisi; } \\
\text { Sarana: gardu listrik }\end{array}$ \\
\hline 7 & 66 & $\begin{array}{l}\text { jaringan telekomunikasi dan } \\
\text { informatika }\end{array}$ & 1 & 0 & Prasarana: jaringan telekomunikasi \\
\hline 8 & 67 & jaringan sumber daya air & 1 & 0 & Prasarana: jaringan sungai, jaringan irigasi \\
\hline \multirow[t]{2}{*}{9} & 68 & $\begin{array}{l}\text { jaringan prasarana } \\
\text { lingkungan }\end{array}$ & 1 & 1 & $\begin{array}{l}\text { Prasarana: jaringan persampahan, jalur evakuasi bencana, } \\
\text { jaringan air limbah, jaringan penerangan jalan, jaringan } \\
\text { drainase; Sarana: TPA, TPST, Ruang Terbuka }\end{array}$ \\
\hline & & & 9 & 4 & \\
\hline B & \multicolumn{2}{|c|}{ Pola Ruang } & & & \\
\hline B1 & \multicolumn{2}{|c|}{ Kawasan Lindung } & & & \\
\hline 1 & 70 & Hutan Lindung & 0 & 0 & \\
\hline \multirow[t]{5}{*}{2} & 71 & $\begin{array}{l}\text { Kawasan yang memberikan } \\
\text { perlindungan di bawahnya }\end{array}$ & 1 & 1 & Prasarana: jaringan ; Sarana: sumur resapan, waduk \\
\hline & 72 & $\begin{array}{l}\text { Kawasan perlindungan } \\
\text { setempat }\end{array}$ & & & \\
\hline & & a. Sempadan Pantai & 1 & 1 & Prasarana: jaringan; Sarana: ruang terbuka hijau \\
\hline & & $\begin{array}{l}\text { b. Sempadan Sungai, } \\
\text { Kawasan Sekitar Waduk, } \\
\text { Embung, Telaga, Laguna }\end{array}$ & 1 & 1 & Prasarana: jaringan; Sarana: ruang terbuka hijau \\
\hline & & c. Sempadan Mata Air & 0 & 1 & Sarana: ruang terbuka hijau \\
\hline \multirow[t]{3}{*}{3} & 73 & Kawasan suaka alam & 0 & 0 & \\
\hline & & a. Kawasan pelestarian alam & 1 & 0 & Prasarana: jaringan \\
\hline & & b. Kawasan cagar budaya & 1 & 0 & Prasarana: jaringan \\
\hline 4 & 74 & Kawasan lindung geologi & 0 & 0 & \\
\hline \multirow[t]{2}{*}{5} & 75 & Kawasan rawan bencana & 0 & 0 & \\
\hline & & & 4 & 3 & \\
\hline $\mathrm{B} 2$ & \multicolumn{2}{|c|}{ Kawasan Budidaya } & & & \\
\hline 1 & 77 & Hutan Produksi & 1 & 0 & Prasarana: jaringan \\
\hline 2 & 78 & Hutan Rakyat & 0 & 0 & \\
\hline 3 & 79 & Pertanian & 1 & 0 & Prasarana: jaringan Prasarana utama \\
\hline 4 & 80 & Perkebunan & 0 & 0 & \\
\hline 5 & 81 & Perikanan & 0 & 0 & \\
\hline 6 & 82 & Pertambangan & 0 & 0 & \\
\hline 7 & 83 & $\begin{array}{l}\text { Kawasan Peruntukan } \\
\text { Industri }\end{array}$ & 1 & 0 & $\begin{array}{l}\text { Prasarana: unit pengolahan limbah, penyediaan ruang terbuka } \\
\text { hijau, penyediaan gudang dan lahan parkir }\end{array}$ \\
\hline 8 & 84 & Pariwisata & 0 & 0 & \\
\hline 9 & 85 & Permukiman & 1 & 1 & $\begin{array}{l}\text { Prasarana: utilitas umum (sistem pembuangan air limbah, sistem } \\
\text { pembuangan air hujan, sistem prasarana air bersih, dan sistem } \\
\text { pembuangan sampah; Sarana: perumahan, perdagangan dan jasa, } \\
\text { sarana olahrga, sarana pendidikan, dan industri rumah tangga, } \\
\text { ruang terbuka hujan }\end{array}$ \\
\hline \multirow[t]{2}{*}{10} & 86 & Pesisir dan laut & 0 & 0 & \\
\hline & & & 4 & 1 & \\
\hline
\end{tabular}

Sumber: Hasil Analisis, 2019

Keterangan Tabel: 1 ada, 0 tidak ada 
C. Kelengkapan Standart Minimal Prasarana dan Sarana sesuai dengan tabel 3, menunjukkan:

a. Pada ruang yang dilewati sistem jaringan, 9 Pasal yang mengatur standart minimal prasarana dan sarana, hanya 4 pasal yang mengatur keduanya dan 5 pasal hanya mengatur ketentuan prasarana;

b. Pada kawasan lindung, 5 pasal yang mengatur aturan zonasi, hanya 4 Pasal dilengkapai standart minimal prasarana dan 3 Pasal dilengkapi ketentan sarana;

c. Pada kawasan budidaya, dari sepuluh pasar yang mengatur ketentuan umum zonasi, hanya 4 pasal yang mengatur ketentuan standart minimal prasarana, dan hanya 1 pasal yang mengarur keduanya.



Aturan Aturan Standart Minimal Prasarana dan Sarana Ruang di Kawasan Budidaya

Gambar 4. Grafik Kelengkapan Standart Minimal Prasarana dan Sarana Sumber: Tabel 3, 2016

Berdasarkan hasil kajian 3 parameter utama ketentuan zonasi, sesuai standart minimal yang digariskan oleh Peraturan Meneri ATR No. 1 Tahun 2018, menunjukkan banyak hal yang luput/terlewat dari pembahasan (lihat simbol 0) dalam grafik. Dari 24 Pasal yang dikaji, terlihat tidak semua menjelaskan upaya pengaturan ketentuan kegiatan, 
ketentuan intensitas bangunan dan ketentuan standart minimal penyediaan sarana dan prasarana. Pada ketentuan kegiatan bersyarat, aturan yang memuat ketentuan bersyarat hanya $12,5 \%$. Aturan bersyarat yang sudah ada inipun belum tentu menjelaskan syaratnya apa yang harus dipenuhi dalam izin pemanfaatan ruang. Pada ketentuan intensitas, jumlah aturan yang megatur koefisien bangunan 0,083\%, mengatur koefisien lantai bangunan 0\%, dan mengatur koefisien dasar hijau 25\% Sebagai akibatnya ketika mengajukan izin pemanfaatan ruang yang kemudian mengarah ke izin mendirikan bangunan, rambu-rambu pengaturan intensitas bangunan tidak ada sementara Rencana Detail Tata Ruang juga belum siap digunakan sebagai acuan perizinan. Pada aturan standart minimal saranaprasarana, $75 \%$ aturan sudah mencatumkan spasyarat prasarana dan $25 \%$ sudah mengatur sarana. Pada kasus perizinan pembangunan perumahan ataupun industri serta pembangunan kegiatan budidaya lainnya, fasilitas yang seharsnya ditangung atau disediakan oleh pengembang akan luput.

Beberapa faktor yang mempengaruhi rendahnya kualitas produk dari alat pengendalian (KUPZ) di RTRW Kabupaten Kendal ini diantaranya adalahlah:

a. Stake holder kurang paham terhadap perkembangan peraturan perundangan dan pedoman penyusunan;

b. Penyusuan tidak pahaman terhadap tata cara peyusunan KUPZ RTRW;

c. Stake holder (Pemohon Izin Dan Pemberi Izin) tidak tahu/pura-pura tidak tahu terhadap fungsi KUPZ RTRW;

d. Adanya Kepentingan Lain Yang Lebih Berorientasi Pada Keuntungan Ekonomi Jangka Pendek Atau Politik (5 Tahunan).

Beberapa poin penting yang ditemukan peneliti dari hasil kajian di atas adalah:

1) Kelengkapan materi aturan kegiatan pemanfaatan ruang mengatur kegiatan yang diperbolehkan, diperbolehkan bersyarat dan tidak boleh pada ruang yang dilewati sistem jaringan, dan pada rencana pola ruang secara keseluruhan tidak lengkap, terutama untuk aturan bersyarat (aturan tidak ada dan syarat juga tidak ada);

2) Kelengkapan materi intensitas bangunan sangat minim di ruang yang dilewati sistem jaringan dan di pola ruang hanya ada di kawasan permukiman dan industri, sementara ketentuan minimal untuk KDH dan sempadan lebih banyak diatur di linsung setempat (sempadan) dan jaringan jalan;

3) Kelengkapan standart pelayanan minimal di beberapa pasal sudah ada hanya tidak sesuai dengan standart pelayanan yang dimaksud dalam KUPZ. 
Jurnal Planologi Vol. 16, No. 1, April 2019

4) Banyaknya faktor kepentingan dan ketidak tahuan aturan perundangan dalam penyusunan KUPZ yang mempengaruhi kualitas dari KUPZ;

\section{KESIMPULAN DAN SARAN}

\subsection{Kesimpulan}

Kesimpulan yang bisa diberikan dari hasil kajian ini adalah kualitas KUPZ Kabupaten Kendal masih kurang baik. Banyak materi yang isyaratkan dalam standart minimal untuk penyusunan KUPZ luput/terlewatkan baik berkaitan dengan pengaturan kegiatan maupun pengaturan standart minimal intensitas bangunan dan kelengkapan sarana-prasarananya. Kondisi inilah yang pada kenyataannya menyulitkan pemerintah Kabupaten Kendal untuk berusaha melakukan kegiatan tertib ruang melalui mekanisme pengendalian pemanfaatan ruang. Akibatnya banyak terjadi pelanggaran pemanfaatan ruang dan meningkatkan kejadian bencana alam seperti banjir yang terjadi akhir-akhir ini di Kabupaten Kendal.

\subsection{Saran}

Saran dari hasil kajian untuk perbaikan KUPZ RTRW Kabupaten Kendal adalah:

1) Perbaikan KUPZ sangat dibutuhkan untuk mempermudah implementasi. Tahapan dan proses perbaikan ini akan lebih baik jika dalam penyusunan mengikuti aturan yang ditetapkan dalam peraturan perundangan yang berlaku;

2) Penyusunan kedalaman materi KUPZ minimal mempertimbangkan rencana struktur, rencana pola ruang, arahan umum desain perkotaan dan ketentuan perundangan yang berlaku;

\section{DAFTAR PUSTAKA}

Barnett, J. (1982). An Introduction to Urban Design. Harper \& Row. New York

Denny Zulkaidi danPetrus Natalivan (2008). Pengendalian Pemanfaatan Ruang. Pelatihan

Penyusunan Peraturan Zonasi Ahli Teknik Zonasi I. Badan Pembinaan Konstruksi Dan Sumber Daya Manusia Departemen Pekerjaan Umum. Semarang.

Hasti, F., Rouhi, H,. Khodakarami, I., \& Mahiny, A. S., (2016). Zoning the protected area of Shahoo/Kosalan using RS and GIS. Journal of Environmental Science, Toxicology and Food Technolog. 10 (8), 74-81. 
Jurnal Planologi Vol. 16, No. 1, April 2019 Available : http://jurnal.unissula.ac.id/index.php/psa

Leageu of Minnesota Citie (2017). Information Memo Zoning Guide For Cities League Of Minasota City. University Ave West Saint Paul, MN 55103-2044 Www.Lmc.Org 7/6/2017 (diakses pada 13/02/2019: 10.18)

Mayona, E. L., Urufi, Z., \& Ridwandoni (2009). Pengaturan Zonasi Penggunaan Lahan Di Kawasan Tepian Das Kahayan (Studi Kasus: Kelurahan Pahandut Kota Palangka Raya) Seminarnasional Implikasi UU Penataan Ruang No. 26 Tahun 2007 Terhadap Konsep Pengembangan Kota Dan Wilayah Berwawasan Lingkungan Universitas Brawijaya Malang, 29 April 2009, Hal: 92-104. http://lib.itenas.ac.id/kti/wpcontent/uploads /2012/04/01.-Pengaturan-Zonasi-Penggunaan-Lahan-di-KawasanTepian-DAS-Kahayan1.pdf (diakses 28/03/2019: 07.43)

Merriam, Dwight H. (2005). The Complete Guide To Zoning. McGraw-Hill New York.

Sabatini, M. D. C., Verdiell, A., Iglesias, R. M. R., \& Vidal, M. (2007). A quantitative method for zoning of protected areas and itsspatial ecological implications. Journal of Environmental Management, 83, 198-206.

Walther, P. (1986). The meaning of zoning in the management of natural resource lands. Journal of Environmental Management, 22 (1), 331-344.

Dinas PSDA dan Taru (2017). Pengendalian Pemanfaatan Ruang di Kawasan Khusus (kasan Daerah Aliran Sungai) di Provinsi Jawa Tengah.

DPU TARU (2017). Laporan Akhir Kegiatan Monitoring, evaluasi dan pelaporan Peninjauan Kembali RTRW Kabupaten Kendal.

Peraturan Menteri Agraria Dan Tata Ruang/ Kepala Badan Pertanahan Nasional Nomor 1 Tahun 2018 Tentang Pedoman Penyususan RTRW Provinsi, Kabupaten dan Kota Undang-Undang Nomor 26 Tahun 2007 tentang Penataan Ruang 